\title{
Expeditious, Mild and Solvent Free Synthesis of Bis(indolyl)methanes, Using a Mixture of Phosphorus Pentoxide in Methanesulfonic Acid
}

\author{
AMULRAO U. BORSE*, MAHESH N. PATIL AND NILESH L. PATIL \\ School of Chemical Sciences, North Maharashtra University, \\ Jalgaon, 425 001, (M.S), India \\ amulborse@gmail.com
}

Received 13 July 2011; Accepted 20 September 2011

\begin{abstract}
Highly rapid and efficient synthesis of Bis(indolyl)methanes has been developed by using a mixture of phosphorus pentoxide in Methanesulfonic acid (Eaton's reagent) at ambient temperature under solvent free condition.
\end{abstract}

Keywords: Expeditious, ambient temperature, solvent free, Bis(indolyl)methane, Eaton's reagent.

\section{Introduction}

It is an ultimate dream of organic chemist's to perform reactions under solvent free conditions for providing green approach towards organic synthesis. In recent years emphasis is given on the development of environmentally benign procedures and reagents in organic chemistry. With the current global awareness in developing environmentally friendly technologies it was decided to carry out reactions in neat and non-hazardous conditions. This communication describes our efforts towards this.

Eaton's reagent (1:10 phosphorus pentoxide in Methanesulfonic acid) is an inexpensive and commercially available substance synthesized by Philip E. Eaton in 1973, can be used to overcome the disadvantages of polyphosphoric acid as a catalyst for dehydration reactions, because it has a much lower viscosity, it is easier to handle and no complex separation procedures need to be employed. Combination of phosphorus pentoxide and Methanesulfonic acid $\left(\mathrm{P}_{2} \mathrm{O}_{5} / \mathrm{MeSO}_{3} \mathrm{H}\right)$ can also be employed as catalyst for Fisher-Indole synthesis, Beckmann rearrangement and Schmidt rearrangement processes ${ }^{1}$. Many processes that employ a mixture of $\mathrm{P}_{2} \mathrm{O}_{5} / \mathrm{MeSO}_{3} \mathrm{H}$ are not only more economical, they are also more environmentally friendly and offers a number of distinct advantages such as safe in industrial scale, low environmental impact, easy work-up procedures, rapid reactions and high purity products with excellent yields. Mixture of $\mathrm{P}_{2} \mathrm{O}_{5} / \mathrm{MeSO}_{3} \mathrm{H}$ is found to be the efficient reagent mainly used for ring closure, McGarry and Detty successfully use this 
reagent in cycloacylation reactions for producing chromones and flavones ${ }^{2 a}$, recently Zewge and co-workers use Eaton's reagent to promote the cyclization of aniline derivatives to produce 4-quinolones ${ }^{2 \mathrm{~b}}$. $\mathrm{P}_{2} \mathrm{O}_{5} / \mathrm{MeSO}_{3} \mathrm{H}$ offers a simple means of producing poly(benzimidazoles) from o-phenylenediamines and aromatic carboxylic acids ${ }^{2 \mathrm{c}}$. Furthermore it is an excellent medium for producing substituted oxazoles by cyclocondensation aroyl amidoacetals ${ }^{2 \mathrm{~d}}$. Kaboudin et.al. employed this system for synthesis of aryl mesylates ${ }^{2 \mathrm{e}}$.

Indole is one of the privileged molecules of organic chemistry as several of its derivatives are valuable pharmaceuticals ${ }^{3}$. During the past few years a large number of natural products containing Bis(indolyl)methane ${ }^{4}$ and Bis(indolyl)ethane ${ }^{5}$ moieties have been isolated from marine sources. Bis(indolyl)methanes are cruciferous substances useful for promoting beneficial estrogen metabolism in men and women ${ }^{6}$. They are also effective in the prevention of cancer due to their ability to modulate certain cancer causing estrogen metabolism ${ }^{7}$. Moreover these compounds may normalize abnormal cell growth associated with cervical dysplasia ${ }^{8}$. The most ubiquitous of the known bioactive alkaloids are based on the indole moiety ${ }^{9}$. Vibrindole A has been demonstrated for the first time to exhibit antibacterial activity against $S$. aureus, $S$. albus and B. subtills. Gentamycin is in use as a standard antibacterial $\operatorname{drug}^{10}$.

A variety of synthetic methodologies using acid catalysts, such as protic acids [11], Lewis $\operatorname{acids}^{12,13}$, heterogeneous acid catalysts ${ }^{14,15}$, ionic liquids ${ }^{16,17}, \mathrm{P}_{2} \mathrm{O}_{5} / \mathrm{SiO}_{2}{ }^{18}$ have been developed for the preparation of Bis(indolyl)methanes, but many of these reported protocols suffered from usage of expensive reagents, prolonged reaction time, hazardous solvents, tedious workup methods and give unsatisfactory yields. In view of this it was decided to use Eaton's reagent under solvent free conditions at room temperature using simple work-up procedure for the synthesis Bis(indolyl)methane (Scheme 1).

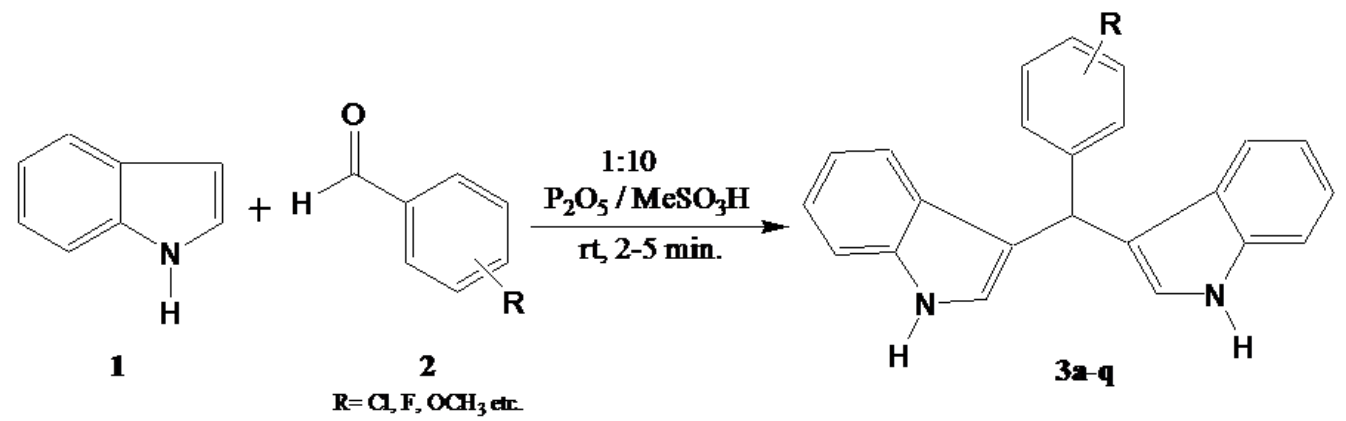

Scheme 1. Synthesis of Bis(indolyl)methanes using Eaton's reagent.

\section{Experimental}

All melting points were recorded in open capillaries and are uncorrected, compared with reported values. The compounds were purified by column chromatography and the purity was checked by TLC on silica gel G (Merck). ${ }^{1} \mathrm{H}$ NMR spectra were recorded in $\mathrm{CDCl}_{3}$ using TMS as the internal standard on Varian $300 \mathrm{MHz}$ instrument. IR spectra were obtained using Nujol on a Perkin-Elmer-1710 spectrophotometer. Mass spectra were recorded on a Thermo Finnigan (Model-LCQ Advantage MAX) mass spectrometer. 
Table 1. Comparison of reaction conditions and the yield of product 3a with reported methods.

\begin{tabular}{llllll}
\hline Entry & Reagent & Conditions & Time & Yield & Ref. \\
\hline 1 & & Grinding & $30 \mathrm{~min}$ & 94 & 18 \\
2 & $\mathrm{P}_{2} \mathrm{O}_{5} / \mathrm{SiO}_{2}$ & Grinding & $10 \mathrm{~min}$ & 94 & 21 \\
3 & $\mathrm{HBF}_{4}-\mathrm{SiO}_{2}$ & Ethanol, U. S.,20 $0^{0} \mathrm{C}$ & $15 \mathrm{~min}$ & 93 & 22 \\
4 & Silicotungstic acid & Solvent free, rt & $40 \mathrm{~min}$ & 92 & 25 \\
5 & $\mathrm{PEG}$ Suppo. sulfonic acid & Methanol, rt & $2.5 \mathrm{hr}$ & 95 & 26 \\
6 & $\left(\mathrm{CO}_{2} \mathrm{H}\right)_{2} \cdot 2 \mathrm{H}_{2} \mathrm{O} / \mathrm{CTAB}$ & Water, rt & $1.5 \mathrm{hr}$ & 98 & 27 \\
7 & $1: 10 \mathrm{P}_{2} \mathrm{O}_{5} / \mathrm{MeSO}_{3} \mathrm{H}$ & Solvent free, rt & $2 \mathrm{~min}$ & 93 & -- \\
\hline
\end{tabular}

General procedure for the synthesis of Bis(indolyl)methanes:-

Eaton's reagent $(1.0 \mathrm{mmol})$ was added to a mixture of Indole $(2.0 \mathrm{mmol})$ and aldehyde $(1.0$ $\mathrm{mmol}$ ) in a round bottom flask and stirred vigorously at room temperature for appropriate time (mentioned in Table 1). After completion of the reaction (monitored by TLC), the reaction mass was transferred to an excess saturated sodium carbonate solution. The solid product separated out, was filtered, washed with sufficient water and dried. The crude products were recrystalized from ethanol-water $(1: 1)$ or column chromatographed on silica gel using ethyl acetate / hexane as eluent to afford substituted Bis(indolyl)methanes in 78$93 \%$ yield (Scheme 1).

Table 2. Effect of molar ratio on the condensation of Indole $(2 \mathrm{mmol})$ with benzaldehyde(1 mmol) to produce (3a).

\begin{tabular}{llll}
\hline Entry & Eaton's reagent & Reaction time & Yield $^{\mathrm{a}}$ \\
\hline 1 & $0.5 \mathrm{mmol}$ & $4-5 \mathrm{~min}$ & $88 \%$ \\
2 & $1.0 \mathrm{mmol}$ & $2 \mathrm{~min}$ & $93 \%$ \\
3 & $1.5 \mathrm{mmol}$ & $2 \mathrm{~min}$ & $93 \%$ \\
4 & $2.0 \mathrm{mmol}$ & $2 \mathrm{~min}$ & $92 \%$ \\
\hline
\end{tabular}

${ }^{\mathrm{a}}$ Isolated yield.

Physical and Spectral data for the selected compounds:-

3-((1H-indol-3-yl)(phenyl)methyl)-1H-indole (3a)

Pink solid; Yield 93\%; mp 124-126 ${ }^{\circ} \mathrm{C}$; IR(Nujol): 3389, 1598, 1458, 1377, 1215, 1122 , 1089, 739, $700 \mathrm{~cm}^{-1} ;{ }^{1} \mathrm{H}$ NMR $\left(300 \mathrm{MHz}, \mathrm{CDCl}_{3}\right): \delta \mathrm{H} 5.88(1 \mathrm{H}, \mathrm{s}), 6.64(2 \mathrm{H}, \mathrm{s}), 7.00(2 \mathrm{H}, \mathrm{t}$, $J=7.6 \mathrm{~Hz}), 7.16(2 \mathrm{H}, \mathrm{t}, J=7.6 \mathrm{~Hz}), 7.21-7.40(9 \mathrm{H}, \mathrm{m}), 7.88(2 \mathrm{H}, \mathrm{br} \mathrm{s}, \mathrm{NH}) ; \mathrm{MS} \mathrm{m} / \mathrm{z}: 321(\mathrm{M}-$ 1), 206, 116.

3-((2,4-dichlorophenyl)(1H-indol-3-yl)methyl)-1H-indole (3d)

White solid; Yield 92\%; mp 140-142 ${ }^{\circ} \mathrm{C}$; IR(Nujol): 3403, 1459, 1153, 1090, 863, 738, 722 $\mathrm{cm}^{-1} ;{ }^{1} \mathrm{H}$ NMR $\left(300 \mathrm{MHz}, \mathrm{CDCl}_{3}\right): \delta \mathrm{H} 6.27(1 \mathrm{H}, \mathrm{s}), 6.63(2 \mathrm{H}, \mathrm{s}), 6.99-7.44(11 \mathrm{H}, \mathrm{m})$, 7.93(2H, br s, NH); MS m/z: 389 (M-1), 274, 146, 116.

3-((2,3-dichlorophenyl)(1H-indol-3-yl)methyl)-1H-indole (3f)

White solid; Yield 86\%; mp 112-114 ${ }^{\circ} \mathrm{C}$; IR(Nujol): 3384, 1459, 1151, 1086, 1038, 768, 722 $\mathrm{cm}^{-1} ;{ }^{1} \mathrm{H}$ NMR $\left(300 \mathrm{MHz}, \mathrm{CDCl}_{3}\right): \delta \mathrm{H} 6.36(1 \mathrm{H}, \mathrm{s}), 6.63(2 \mathrm{H}, \mathrm{s}), 7.00-7.39(11 \mathrm{H}, \mathrm{m}), 7.94(2 \mathrm{H}$, br s, NH); MS m/z: 389 (M-1), 274, 146, 116. 
4-(Di(1H-indol-3-yl)methyl)phenol (3o)

Pink solid; Yield 78\%; mp 122-124 ${ }^{\circ} \mathrm{C}$; IR(Nujol): 3444, 3400, 1612, 1596, 1510, 1459 ,

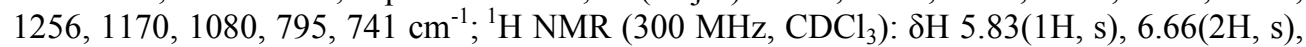
6.74( $(2 \mathrm{H}, \mathrm{d}, J=8.1 \mathrm{~Hz}), 7.0(2 \mathrm{H}, \mathrm{t}, J=8 \mathrm{~Hz}), 7.14-7.40(8 \mathrm{H}, \mathrm{m}), 7.92(2 \mathrm{H}, \mathrm{br} \mathrm{s}, \mathrm{NH}) ; \mathrm{MS} \mathrm{m} / \mathrm{z}$ : 337 (M-1), 222, 116, 105.

3-((1H-indol-3-yl)(3,4,5-trimethoxyphenyl)methyl)-1H-indole (3p)

Yellow solid; Yield 81\%; mp 222-224 ${ }^{\circ} \mathrm{C}$; IR(Nujol): 3377, 1592, 1459, 1219, 1121, 990, $737 \mathrm{~cm}^{-1} ;{ }^{1} \mathrm{H}$ NMR $\left(300 \mathrm{MHz}, \mathrm{CDCl}_{3}\right): \delta \mathrm{H} 3.71(6 \mathrm{H}, \mathrm{s}), 3.83(3 \mathrm{H}, \mathrm{s}), 5.81(1 \mathrm{H}, \mathrm{s}), 6.59(2 \mathrm{H}$, s), 6.69(2H, s), 7.01(2H, t, $J=7.4 \mathrm{~Hz}), 7.16(2 \mathrm{H}, \mathrm{t}, J=7.6 \mathrm{~Hz}), 7.34-7.42(4 \mathrm{H}, \mathrm{m}), 7.94(2 \mathrm{H}, \mathrm{br}$ s, NH); MS m/z: 411 (M-1), 296, 116.

3-((1H-indol-3-yl)(4-methoxyphenyl)methyl)-1H-indole (3q)

Pink solid; Yield 92\%; mp 186-188 ${ }^{\circ} \mathrm{C}$; IR(Nujol): 3484, 1607, 1507, 1459, 1417, 1243 , 1090, 1008, 782, $738 \mathrm{~cm}^{-1} ;{ }^{1} \mathrm{H}$ NMR $\left(300 \mathrm{MHz}, \mathrm{CDCl}_{3}\right): \delta \mathrm{H} 3.78(3 \mathrm{H}, \mathrm{s}), 5.84(1 \mathrm{H}, \mathrm{s})$, $6.63(2 \mathrm{H}, \mathrm{s}), 6.82(2 \mathrm{H}, \mathrm{d}, J=8.6 \mathrm{~Hz}), 7.00(2 \mathrm{H}, \mathrm{t}, J=7.4 \mathrm{~Hz}), 7.16(2 \mathrm{H}, \mathrm{t}, J=7.65 \mathrm{~Hz})$, $7.25(2 \mathrm{H}, \mathrm{d}, J=8.6 \mathrm{~Hz}), 7.33-7.40(4 \mathrm{H}, \mathrm{m}), 7.86(2 \mathrm{H}$, br s, NH); MS m/z: 351 (M-1), 236, 116.

Table 3. Synthesis of Bis(indolyl)methanes(3a-3q) using Eaton's reagent ${ }^{\mathrm{a}}$.

\begin{tabular}{|c|c|c|c|c|c|c|}
\hline \multirow[t]{2}{*}{ Entry } & \multirow[t]{2}{*}{ Aldehyde } & \multirow[t]{2}{*}{ Product } & \multirow{2}{*}{$\begin{array}{l}\text { Time } \\
(\min )\end{array}$} & \multirow{2}{*}{$\begin{array}{l}\text { Yield } \\
(\%)^{\mathrm{b}}\end{array}$} & \multicolumn{2}{|c|}{ Melting Point $\left({ }^{\circ} \mathrm{C}\right)$} \\
\hline & & & & & Found & $\begin{array}{l}\text { Report. } \\
\text { Ref. }\end{array}$ \\
\hline 1 & & $3 a$ & 2 & 93 & $\begin{array}{l}124- \\
126\end{array}$ & $\begin{array}{l}125-126 \\
12 a\end{array}$ \\
\hline 2 & & $3 b$ & $2-3$ & 93 & $82-84$ & $80-82^{21}$ \\
\hline 3 & & $3 c$ & 2 & 91 & $74-76$ & $78-80^{18}$ \\
\hline 4 & & $3 d$ & $2-3$ & 92 & $\begin{array}{l}140- \\
142\end{array}$ & $\begin{array}{l}141-143 \\
22\end{array}$ \\
\hline 5 & & $3 \mathrm{e}$ & $2-3$ & 90 & $\begin{array}{l}110- \\
112\end{array}$ & $\begin{array}{l}110-112 \\
24\end{array}$ \\
\hline 6 & & $3 \mathrm{f}$ & $2-3$ & 86 & $\begin{array}{l}112- \\
114\end{array}$ & -- \\
\hline 7 & & $3 g$ & 5 & 89 & $\begin{array}{l}110- \\
112\end{array}$ & $\begin{array}{l}110-112 \\
23\end{array}$ \\
\hline 8 & & $3 \mathrm{~h}$ & 2 & 90 & $\begin{array}{l}138- \\
140\end{array}$ & $\begin{array}{l}139-141 \\
18\end{array}$ \\
\hline 9 & & $3 \mathrm{i}$ & 2 & 90 & $\begin{array}{l}220- \\
222\end{array}$ & $\begin{array}{l}220-222 \\
18\end{array}$ \\
\hline
\end{tabular}


10

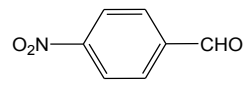

11

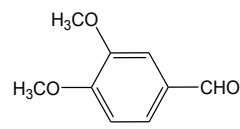

12

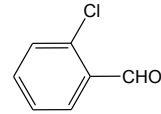

13

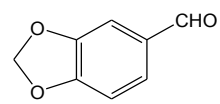

14

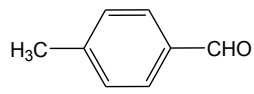

15

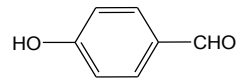

16<smiles>COc1cc(C=O)cc(OC)c1OC</smiles>

17

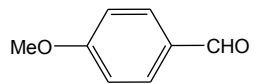

$3 \mathrm{j}$

$3 \mathrm{k}$

31

$3 m$

$3 n$

30

$3 p$

$3 q$
2

4-5

2

5

4-5

4-5

5

81

92

84

82

83
222- $\quad 217-219$

224

198- $198-200$

200

19

$72-76 \quad 70-71^{20}$

$100-$

102

176- $\quad 176-178$

$178 \quad 12 \mathrm{a}$

122- $\quad 119-121$

$124 \quad 18$

222-

224

186- $186-187$

$188 \quad 12 \mathrm{a}$

${ }^{a}$ Reactions conditions: Indole $(2.0 \mathrm{mmol})$, Aldehyde $(1.0 \mathrm{mmol})$, Eaton's reagent $(1.0$ mmol). ${ }^{\mathrm{b}}$ Isolated yield.

\section{Result and Discussion}

Herein, we report an efficient protocol for the rapid synthesis of a variety of biologically important Bis(indolyl)methanes using Eaton's reagent under extremely mild conditions. Eaton's reagent is colorless, odorless liquid mixture of non oxidizing Methanesulfonic acid and a powerful dehydrating agent phosphorus pentoxide. The addition of phosphorus pentoxide increases the solubility of organic compounds in Methanesulfonic acid; this was introduced by Eaton and has been used enormously in organic synthesis.

In a typical experimental procedure, $1.0 \mathrm{mmol}$ of aldehyde, $2.0 \mathrm{mmol}$ of Indole and 1.0 mmol of Eaton's reagent were stirred for 2-5 min at room temperature, (monitored by TLC). After completion of the reaction, using simple work-up offered Bis(indolyl)methanes in high yields. The products are purified by recrystalization from aqueous ethanol or purified by column chromatography using hexane-ethyl acetate as eluent.

In order to standardize the reaction conditions for the condensation reaction it was decided to synthesize Bis(indolyl)methanes (3a) from indole and benzaldehyde using Eaton's reagent (Table 1). The results are compared with the reported methods and it is clear from Table 1, that the present method is more efficient.

The reaction was carried out by changing the amount of the Eaton's reagent (Benzaldehyde used as model). By using $0.5 \mathrm{mmol}$ of Eaton's reagent it gives $88 \%$ of yield, $1.0 \mathrm{mmol}$ gives $93 \%$ yield (Table 2, Entry 2) and $1.5 \mathrm{mmol}$ also provides $93 \%$ yield, further 
increasing amount of Eaton's reagent did not affect the yield and reaction time. Therefore it was found that the $1.0 \mathrm{mmol}$ of reagent was sufficient to push the reaction into completion with high to excellent yield (Table 2).

To explore the scope of this reaction, we extended the procedure for the synthesis of variety of Bis(indolyl)methanes using various aromatic aldehydes possessing either electronreleasing or electron-withdrawing substituent's in the ortho, meta and para positions (results summarized in Table 3). It is observed that the reaction proceeds very efficiently with all the aldehydes, substituents on the aromatic ring effect the conversion rate, aldehydes having electron-withdrawing groups on the aromatic ring (Table 3,Entries 2-6, 8-10) react faster than electron-donating groups (Table 3, Entries 7, 11, 13-17). Important features of this procedure are that it is carried out under mild conditions; works well with all aldehydes having functional groups (methyl, methoxy, nitro and halides) and provides the final products in high yields.

\section{Conclusion}

In summary, the present methodology offers very attractive features such as shorter reaction times, simple operations with extremely milder conditions, green aspects avoiding hazardous organic solvents, toxic catalyst and waste, good to excellent yields with the help of an inexpensive and commercially available Eaton's reagent as a powerful substance for the synthesis of Bis(indolyl)methanes at ambient temperature.

\section{Acknowledgments}

This work is supported by the University Grant Commission (UGC), New Delhi for providing grant to the School of Chemical Sciences, North Maharashtra University (Jalgaon) under SAP program. One of the authors (MNP) acknowledges UGC, New Delhi for SAP fellowship under the scheme 'Research Fellowship in Sciences for Meritorious Students'. Authors are also thankful to Prof. R. S. Mali for his valuable guidance.

\section{References}

1. (a) Eaton P E, Carlson G R and Lee J T, J. Org. Chem., 1973, 38, 4071; (b) Eaton's reagent (7.7/92.3 \% by weight of $\left.\mathrm{P}_{2} \mathrm{O}_{5} / \mathrm{MeSO}_{3} \mathrm{H}\right)$ was purchased from Sigma-Aldrich.

2. For Eaton's reagent mediated reactions, see: (a) McGarry L W and Detty M R, J. Org. Chem., 1990, 55, 4349; (b) Zewge D, Chen C, Deer C, Doner P G and Hughes D L, J. Org. Chem., 2007, 72, 4276; (c) Fomenkov A I, Blagodatskikh I V, Ponomarev Iv I, Volkova Yu A, Ponomarev I I, Khokhlov A R and Polymer Science, 2009, 51, 166; (d) Pandit C R, Polniaszek R P, Thottathil J K and Synth. Commun., 2002, 32(15), 2427; (e) Kaboudin B and Abedi Y, Synthesis, 2009, 12, 2025-2028; (f) Park S, Lee J and Lee K, Bull. Korean Chem Soc., 2007, 28, 1203; (g) Pandit C R, Polniaszek R P and Thottathil J K, Synth. Commun., 2002, 32(15), 2427; (h) Srikrishna A and Dethe D H, Org. Lett., 2003, 5(13), 2295; (i) Glasnov T M, Stadlbauer W and Kappe C O, J. Org. Chem., 2005, 70, 3864; (j) Runyon S P, Mosier P D, Roth B L, Glennon R A and Westkaemper R B, J. Med. Chem., 2008, 51, 6808; (k) Jayaraman M, Fox B M, Hollingshead M, Kohlhagen G, Pommier Y and Cushman M, J. Med. Chem., 2002, 45, 242.

3. (a) Carey F A and Sundberg R J, Advanced Organic Chemistry; Part B: Reaction and Synthesis, $5^{\text {th }}$ edition, Plenum Press: New York, 2007.; (b) Sundberg R J, The chemistry of Indoles; Academic Press: New York, 1996,113.

4. Morris S A and Anderson R J, Tetrahedron, 1990, 46, 715.

5. Bifulco G, Bruno I, Riccio R, Lavayre J and Bourdy G, J. Nat. Prod. 1995, 58, 1254.

6. Zeligs M A, J. Medicinal Food, 1998, 1, 67. 
7. Michnovics J J and Bradlow H L, Food phytochemicals I: Fruits and Vegetables, 1993, 282.

8. Bell M C, Gynecologic Oncology, 2000, 78, 123.

9. (a) Gribble G W, In comprehensive Heterocyclic Chemistry, $2^{\text {nd }}$ edition, Pergamon Press: New York, 1996, 202; (b) Snieckus V, In The Alkaloids, Academic Press: New York, 1998,11.

10. Hong C, Firestone G L and Bjeidanes L F, Biochem. Pharmaco., 2002, 63, 1085.

11. (a) Roomi M and MacDonald S, Can J Chem., 1970, 48, 139; (b) Gregorovich B, Liang K, Clugston D and MacDonald S, Can J Chem., 1968, 46, 3291.

12. (a) Noland W E, Venkiteswaran M R and Richards C G, J. Org. Chem., 1961, 26, 4241; (b) Banerji J, Chatterjiee A, Manna S, Pascard C, Prange T and Shoolery J, Heterocycles, 1981,15, 325.

13. Chatterjee A, Manna S, Benerji T and Shoolery J, J. Chem. Soc. Perkin I, 1980, 553.

14. Bartoli G, Bosco M, Foglia G, Giuliani A, Marcantoni E and Sambri L, Synthesis, 2004, 895.

15. Kamble V T, Kadam K R, Joshi N S and Muley D B, Catal. Commun., 2007, 8, 498.

16. Sadaphal S A, Shelke K F, Sonar S S and Shingare M S, Cent. Eur. J. Chem. 2008, 6(4), 622.

17. Yadav J S, Reddy B S and Sunita S, Adv. Synth. Catal., 2003, 3, 349.

18. Alireza H, Abdolkarim Z, Hashem S and Khodabakhsh N, Arkivoc 2007, (xiv), 39.

19. Yadav J S, Reddy B V S, Murthy V S R, Kumar M and Madan Ch., Synthesis, 2001, 783.

20. Kamal A and Qureshi A A, Tetrahedron, 1963, 19, 513.

21. Bandgar B P, Patil A V, and Kamble V T, Arkivoc, 2007, (xvi), 252.

22. Ji-Tai L, Zhang X and Song Y, Int. J. ChemTech Res., 2010, 2, 341.

23. Reddy A V, Ravinder R, Reddy V L N, Gould T V, Ravikanth V and Venkateseswarlu Y, Synth. Commun., 2003, 33, 3687.

24. Ghorbani-Veghel R, Velsi H, Keypour H and Dehghani-Flrouzabadi A A, Mol Divers., 2010, $14,87$.

25. Pore D M, Desai U V, Thopte T S and Wadgaonker P P, Arkivok, 2006, (xii), 75.

26. Sheng S R, Wang Q, Ding Y, Liu X and Cai M, Catal. Lett., 2009, 128, 418.

27. Ramin G, Hojat V, Hassan K and Ahmed A D, Mol. Divers., 2010, 14, 87. 


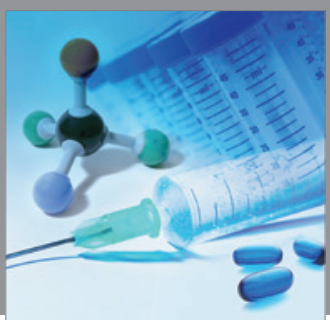

International Journal of

Medicinal Chemistry

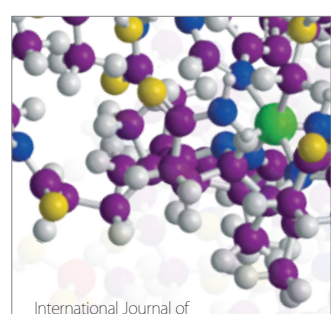

Carbohydrate Chemistry

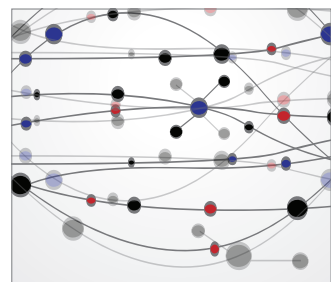

The Scientific World Journal
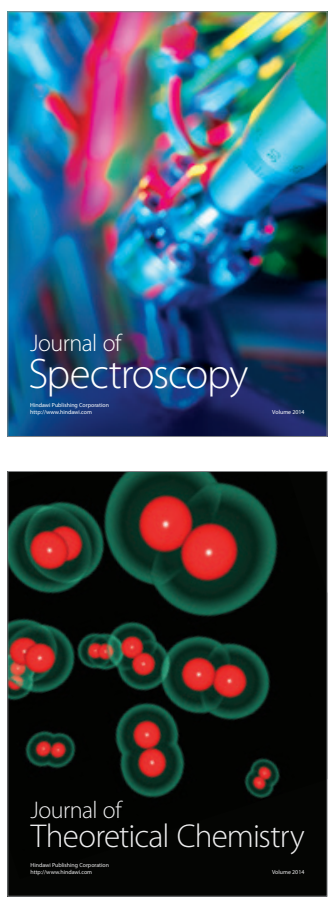
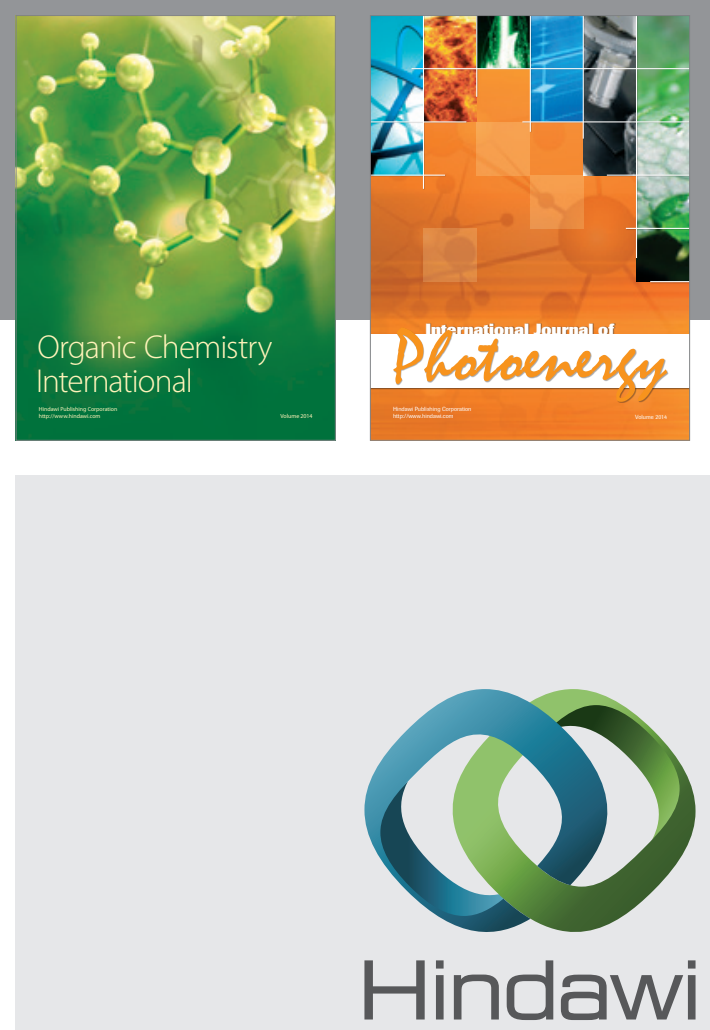

Submit your manuscripts at

http://www.hindawi.com
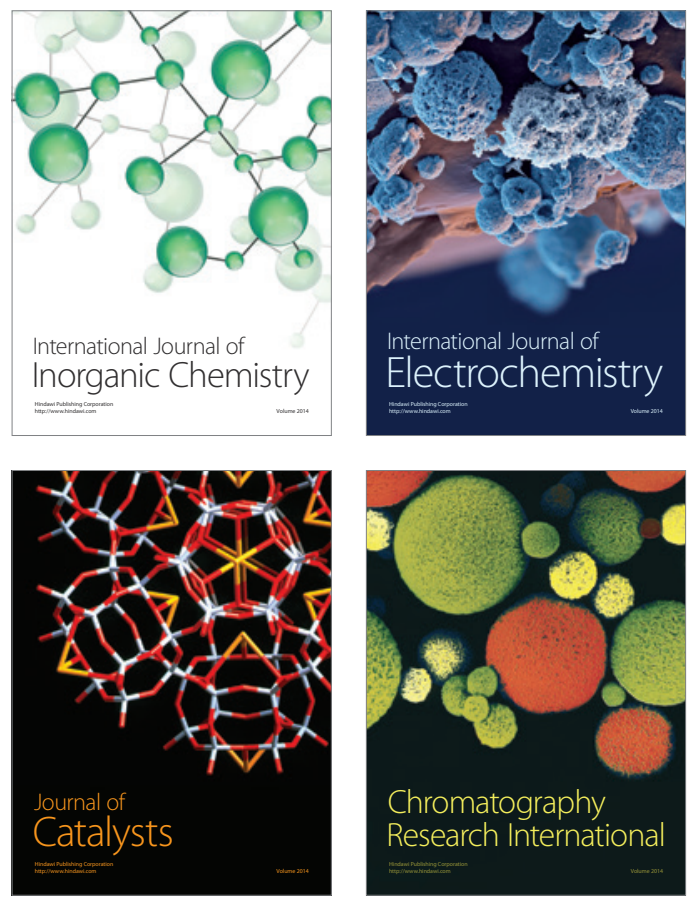
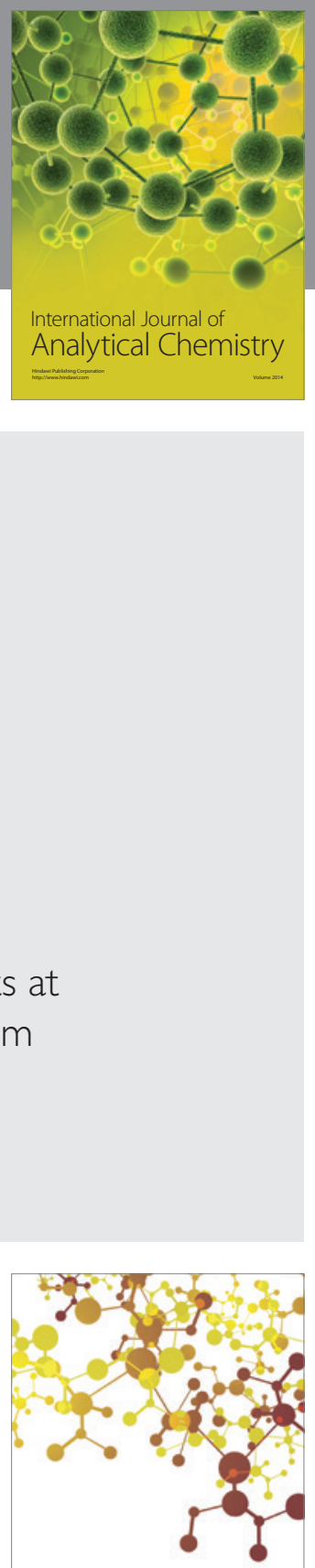

Journal of

Applied Chemistry
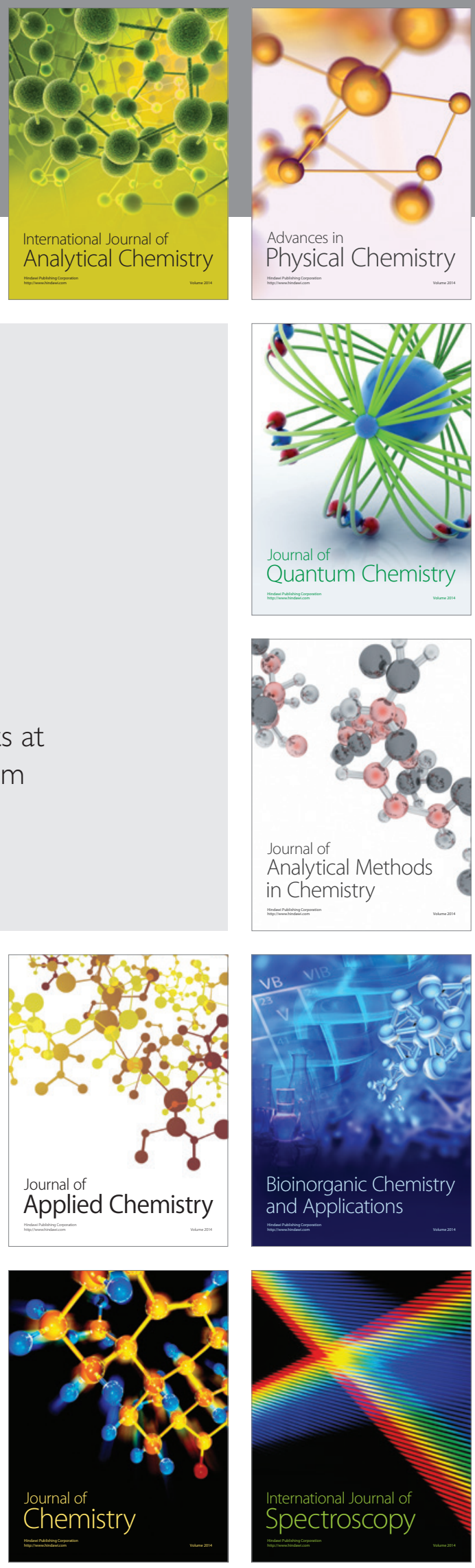